\title{
Stem dimensional fluctuation in Jeffrey pine from variation in water storage as influenced by thinning and prescribed fire
}

\author{
Robert M. Fecko, Roger F. Walker*, Wesley B. Frederick, Watkins W. Miller, Dale W. Johnson
}

University of Nevada, Department of Natural Resources and Environmental Science, 1000 Valley Road, Reno, NV 89512 USA

(Received 7 June 2007; accepted 5 October 2007)

\begin{abstract}
Forest thinning utilizing cut-to-length and whole-tree harvesting systems with subsequent underburning were assessed for their impacts on water storage in the extensible tissues of dominant and codominant trees in an uneven-aged Jeffrey pine (Pinus jeffreyi Grev. \& Balf.) stand on the east slope of the Sierra Nevada. Prior to the onset of the third growing season following thinning and the second season after burning, manual band dendrometers were installed at breast height on the selected trees and readings of diurnal fluctuation in stem circumference, an indication of bole water status, were taken monthly for one year. Diameter and relative diameter fluctuation were calculated from the circumference measurements. Overall, thinning had a positive influence on stem water recharge capacity, with the most pronounced effects evident in the latter part of the growing season. During this period, bole contraction in thinned stand portions was 49 to $55 \%$ greater than in the unthinned control, suggesting that both a greater volume of stored water was available for transpiration and was transpired in trees of the former treatment. There was no clear evidence that harvesting method affected stem water storage and influences of underburning were also absent entirely. Seasonal effects on diurnal changes in stem diameter were prominent, as the extent to which boles contracted generally increased over the course of the growing season, whereas fluctuations were at a minimum during the colder months. The magnitude of stem dimensional flux was found to be negatively correlated with initial tree DBH in one instance, while negative relationships between the former and live crown length as well as percentage were also revealed, albeit infrequently. Changes in bole size were positively correlated with residual basal area in some cases. These results suggest that improvement in water relations can be realized from density management in a dry site forest type with no apparent compromise of this benefit by broadcast underburning.
\end{abstract}

forest thinning / prescribed fire / tree water storage / band dendrometer / Pinus jeffreyi

Résumé - Fluctuations dimensionnelles chez Pinus jeffreyi Grev. \& Balf. et variations dans le stockage d'eau influencées par l'éclaircie et le feu prescrit. Les éclaircies en forêt utilisant les systèmes de débit à la scie et de récolte de l'ensemble de l'arbre avec ultérieurement un brûlage par le bas ont été évaluées pour leurs impacts sur le stockage en eau dans les tissus extensibles des arbres dominants et codominants dans un peuplement inéquienne de Pinus jeffreyi Grev. \& Balf sur le versant est de la Sierra Nevada. Avant le début de la troisième année de croissance suivant l'éclaircie et la deuxième saison après le feu, des dendromètres manuels à bande ont été installés à hauteur de poitrine sur des arbres sélectionnés et la lecture des fluctuations journalières de la circonférence des arbres, une indication sur le statut hydrique du tronc, étaient faite mensuellement pendant une année. Le diamètre et les fluctuations de diamètre ont été calculés à partir des mesures de circonférence. En général, l'éclaircie a une influence positive sur la capacité de recharge en eau du tronc, avec les effets évidents les plus prononcés dans la dernière partie de la saison de croissance. Pendant cette période, la contraction du tronc dans les parties éclaircies des peuplements était de 49 à $55 \%$ plus grande que le témoin non éclairci, suggérant qu'à la fois un plus grand volume d'eau stocké était disponible pour la transpiration et était transpiré par les arbres du premier traitement. Il n'y a pas une preuve claire que la méthode de récolte affecte le stockage d'eau dans le tronc et l'influence du brûlage était aussi totalement absente. Les effets saisonniers sur les changements diurnes du diamètre du tronc étaient proéminents, alors que l'importance des troncs contractés s'est accrue généralement dans le courant de la saison de croissance tandis que les fluctuations ont été au minimum pendant les mois froids de l'année. Dans un cas, l'ampleur de la dimension du flux a été trouvée corrélée négativement avec le diamètre initial, à hauteur de poitrine, de l'arbre, tandis qu'une relation négative entre ce dernier et la longueur de la couronne vivante comme en pourcentage a été aussi révélée, bien que peu fréquemment. Dans quelques cas, les changements dans la taille du tronc ont été positivement corrélés avec la surface terrière résiduelle. Ces résultats suggèrent qu'une amélioration des relations hydriques peut être réalisée par une gestion de la densité des peuplements dans les forêts de zones sèche sans apparemment compromettre ce bénéfice par un brûlage par surface.

Eclaircie en forêt / feu prescrit / stockage d'eau dans l'arbre / dendromètre à bande / Pinus jeffreyi

\section{INTRODUCTION}

Largely because of the impact they have on physiological functioning $[19,20]$, water relations of individual trees are often the primary factor influencing decisions concerning implementation of silvicultural practices in dry site forests such as those existing at the lower to middle elevations of the eastern Sierra Nevada [16, 17]. These forests are composed primarily of Jeffrey pine or ponderosa pine (Pinus ponderosa Dougl.

* Corresponding author: walker@ cabnr.unr.edu ex Laws.) as well as a combination of these two drought tolerant species $[3,16]$ and stands frequently occupy sites with shallow, rocky soils that, when coupled with a nearly complete lack of precipitation during the growing season, predispose extreme competition among trees for soil water, thus limiting growth $[16,17]$ and sometimes compromising stand health $[6,11]$. Likely exacerbating the problem of limited water availability in the eastern Sierra Nevada pine type has been an increase in tree density in these forests over the past century attributed largely to the suppression of periodic surface 
fires that historically arrested the development of dense regeneration [24]. Hence, density management has long been advocated for reducing competition for site resources, thus mitigating the negative impacts of moisture stress in this forest type [15].

Water stored in the extensible tissues of tree boles has been shown to be an important reservoir that is drawn upon during transpiration and which reduces the severity of midday water deficits $[19,20,43]$. This reservoir may be especially significant in dry site forests where drying soils, particularly in the latter part of the growing season, cause soil water movement toward roots to be extremely slow, limiting the nighttime replenishment of moisture in trees after daytime transpiration [22]. Depletion of stored stem water during peak periods of transpiration and recharge of this pool when transpiration rates are low has long been known to be detectable as a decrease followed by an increase, respectively, in bole crosssectional size $[18,21,25]$. Minimal diurnal changes in stem size under drying soil conditions, therefore, likely indicate a lack of nighttime stem water recharge and thus an inability to draw water from this reservoir for transpiration on successive days [23]. Under such an assumption, it should be possible to detect differences in tree water content as affected by silvicultural treatment through the measurement of fluctuation in bole dimensions. However, studies involving direct measurements of the influence of the customary practice of thinning eastern Sierra Nevada pine stands on changes in stem water storage are currently lacking and those examining effects of this treatment on tree water status in general are limited in number [41]. Consequently, such measurements would provide resource managers with an estimate of the magnitude of response and allow for the refinement of thinning protocols used in dry site forests in order to realize management objectives.

The relatively recent adoption of mechanized approaches to implementing forest thinnings [27] and the varying impacts these can have on forest floor and mineral soil properties, which in turn influence water relations [13], necessitates an evaluation of these methods for their effects on the latter. One approach that is becoming more widely accepted in the western United States is that of cut-to-length systems. These involve two machines, one of which processes standing trees into merchantable logs at the stump while a second self-loads the logs into a bunk and forwards them to a landing where they are reloaded for transport to a milling facility. As a consequence of the processor delimbing and topping felled trees on site, these systems leave a large quantity of organic material in the form of slash mats scattered throughout the stand [42]. This accumulated material has the potential benefit of acting as a mulch which creates a barrier to evaporative loss from mineral soil [13], thus enhancing water relations by retaining moisture in the profile later in the growing season. In addition, because both machines travel over the slash mats during much of the thinning operation, mineral soil impacts, particularly compaction and erosion, are minimized. A more common approach to mechanized thinning is that of whole-tree harvesting. In this system, which again involves two machines, one fells entire trees and bunches them while a second skids them to a landing where the delimbing, topping, and buck- ing processes ensue. Compared to cut-to-length systems, this approach leaves little organic debris within the stand and increases mineral soil exposure during repeated skidding cycles, thereby elevating evaporative loss and the possibility of compaction accompanied by reduced infiltration, all forces that can decrease water availability to residual trees. While their differing impacts on the forest floor and soil below seem evident, no documentation of the influence of these two harvesting methods on within-tree water storage in dry site Sierra Nevada forests currently exists.

Prescribed fire, typically in the form of controlled underburning, is increasingly viewed as a means of mimicking historical fire regimes and their ecological roles in fire adapted forest ecosystems of the western United States [1,4], including those of the eastern Sierra Nevada. With regard to water relations, fire can function as a thinning agent targeting young, vulnerable trees $[33,45]$ as noted previously as well as understory vegetation [24], with the removal of both potentially increasing the availability of soil water to residual trees [38]. Alternatively, prescribed underburning in forests of the western United States has been shown to sometimes cause extensive destruction of fine roots [35], which is likely to impair water uptake, as well as considerable bole damage $[30,31,40]$, which may hinder internal water transport and reduce storage capacity. Collectively, these impacts of prescription fire may negate any prospective benefits of the thinning effect where water relations are concerned, although all such assumptions are purely speculative as the influence of this management practice on tree water status and related physiological functioning is unknown.

Presented here are the results of a study that assessed the individual and interactive effects of mechanized thinning and prescribed fire on tree water status in eastern Sierra Nevada Jeffrey pine. Specifically examined were the influences of cutto-length and whole-tree harvesting coupled with broadcast underburning on within-tree water storage as indicated by diurnal stem diameter fluctuation measured throughout the four seasons of a posttreatment year in order to identify the treatment combinations most likely to minimize moisture stress and thereby achieve stand health objectives that are strongly correlated with the latter in this and related forest types. Also presented are relationships between selected stand as well as individual tree variables and stem diameter fluctuation to aid in the determination of factors affecting water storage dynamics.

\section{MATERIALS AND METHODS}

\subsection{Study site}

The site chosen for study consists of a 12.1-ha second growth, naturally regenerated, pure Jeffrey pine stand located in Nevada County, CA on the USDA Forest Service Tahoe National Forest ( $39^{\circ} 25^{\prime} 45^{\prime \prime}$ $\mathrm{N}, 120^{\circ} 8^{\prime} 30^{\prime \prime} \mathrm{W}$ ). At an elevation of $1800 \mathrm{~m}$, this east side Sierra Nevada site has a generally northeast aspect with a slope varying from 3 to $12 \%$. The 55 -year mean annual precipitation is $69 \mathrm{~cm}$, predominantly snow. Soils are of the Kyburz-Trojan complex [39], which is well drained and comprised of a gravelly sandy loam surface layer and an andesitic substratum. 


\subsection{Treatment installation}

In September 2000, the study site was divided equally into three subunits with each randomly designated to receive one of three thinning treatments, specifically a cut-to-length harvesting treatment, a whole-tree harvesting treatment, or an unthinned control. The marking scheme was that of a free thinning [27], with trees in clusters marked such that only the individual exhibiting the best form and largest live crown was to remain wherever possible and with all crown classes of trees between 20.3 and $76.2 \mathrm{~cm}$ DBH having an equal probability of being targeted for removal. Implementation of the thinning treatments followed in October 2000 and was accomplished using a Timberjack Model 1270 processor (Timberjack Forestry Group, Moline, IL) in conjunction with a Timberjack Model 1210 forwarder in the case of the cut-to-length treatment and a Timbco Model 425 feller-buncher (Timbco Hydraulics, Inc., Shawano, WI) combined with a Caterpillar Model 518 grapple skidder (Caterpillar, Inc., Peoria, IL) for the whole-tree treatment. Both treatments were applied concurrently and completed within four days.

The three subunits were then divided into two equal portions each and a prescribed fire treatment was randomly assigned to one of the two portions, with the other within each subunit to remain unburned. In May 2002, a controlled underburn utilizing a strip head fire ignition pattern was conducted on the designated subunit portions, with handlines separating the portions to be burned from those to remain unburned. Ignition commenced at $1800 \mathrm{~h}$ at an air temperature of $16{ }^{\circ} \mathrm{C}$, relative humidity of $48 \%$, wind speed of $5.5 \mathrm{~km} \mathrm{~h}^{-1}$, and fuel moisture content (10-h timelag category) of $10 \%$. The burn was concluded at $2300 \mathrm{~h}$.

\subsection{Mensurational measurements}

During subunit designation, 30 permanent 0.08-ha circular plots were established on the study site, with 10 plots situated within each of the three thinning treatments. For each subunit, five plots were located within the half to be burned while the remaining five were established in the portion selected to remain unburned. Prior to treatment installation, all trees $\geqslant 25.4 \mathrm{~cm} \mathrm{DBH}$ within these plots were measured for total height and DBH, with trees marked for harvest tallied as such. Plot DBH measurements were used to calculate quadratic mean DBH by plot [8], plot basal area, and the basal area retained subsequent to thinning. All basal area calculations were carried out utilizing quadratic mean DBH [9]. In conjunction with the inventory, one unmarked site tree per plot of either dominant or codominant crown class and with good form was randomly selected and cored (4.3- $\mathrm{mm}$ cores extracted $1.37 \mathrm{~m}$ above ground) to determine age and, coupled with tree height, site index using the curves of Meyer [26]. At the beginning of the 2003 growing season, the site trees were measured for total height, $\mathrm{DBH}$, and live crown length, with the latter subsequently used to calculate live crown percentage on the basis of tree height.

\subsection{Stem dimensional fluctuation measurements}

Measurements of diurnal changes in bole circumference were conducted monthly on each of the 30 site trees on 11 cloudless days between May 2003 and April 2004 using an AEC Series 5 Manual Band Dendrometer (Agricultural Electronics Corp., Tucson, AZ) which permitted readings to the nearest $0.1 \mathrm{~mm}$. The metal band portion of the instrument was installed in a level manner around the circumference of each site tree at breast height and the sliding inner vernier scale was initially set near the central reading of the outer scale. On individual measurement days, scale readings were taken once every three hours from one hour before sunrise to one hour after sunset. The maximum diurnal change in circumference was calculated as the difference between the lowest and highest reading of each day, with negative values indicating decreases and positive values increases in this dimension. Subsequently, these values were converted to reflect maximum changes in diameter and to indicate maximum diameter changes as a percentage of the DBH of each site tree (relative changes) as measured prior to the first day of readings.

\subsection{Statistical analyses}

Two-way analysis of variance (ANOVA) was employed to examine differences among the six combinations of three thinning and two prescribed fire treatments in: (1) quadratic mean $\mathrm{DBH}$, tree height, total basal area prior to treatment implementation, and residual basal area subsequent to thinning; and (2) DBH, height, age, and live crown length and percentage of the site trees. For maximum diurnal change in $\mathrm{DBH}$ and DBH relative to initial diameter over the 11 measurement days examined, values were analyzed using repeated measures (mixed model) ANOVA, initially incorporating the compound symmetry covariance structure and then the first-order autoregressive structure. Because the latter covariance structure yielded the lowest value of Akaike's Information Criterion (bias-corrected version, AICC) in models of both variables, those integrating this structure were relied upon for analysis of the data. For each two-way ANOVA, thinning and underburning effects as well as their interaction were considered to be significant only when $p \leqslant 0.05$ according to the $F$ test, while for each repeated measures ANOVA, this significance level was applied in considering the above effects in addition to those of the day of measurement plus all interactions between the latter and the thinning and prescribed fire treatments. All data subsequently underwent mean separation analysis using Duncan's New Multiple Range Test (DNMRT) with $\alpha=0.05$. In the presentation of results that follows, $p$ values are included in the text when a treatment effect proved significant as determined through ANOVA, while the interpretive information concerning differences between individual treatment means provided by DNMRT was considered supplementary in this regard.

Additional statistical analysis consisted of two series of simple linear regressions that were conducted to investigate relationships between selected attributes of the site trees as well as the stand and stem dimensional fluctuation in the former. These regressions were comprised of: (1) models incorporating all of the six treatment combinations included in the study and all combinations of maximum diurnal change in DBH and DBH relative to initial diameter by day of measurement as dependent variables and DBH, live crown length, and live crown percentage of the respective site trees as independent variables; and (2) models incorporating all treatment combinations with the same set of dependent variables as above and with residual stand basal area constituting the independent variable. For each series of regressions, models were considered to be significant only when $p \leqslant 0.05$ according to the $F$ test. All statistical analyses were performed using the Statistical Analysis System (SAS Institute, Inc., Cary, NC). 
Table I. Site tree characteristics by thinning and prescribed fire treatment*.

\begin{tabular}{lccccc}
\hline $\begin{array}{l}\text { Thinning } \\
\text { and fire } \\
\text { treatment }\end{array}$ & $\begin{array}{c}\text { DBH } \\
(\mathrm{cm})\end{array}$ & $\begin{array}{c}\text { Height } \\
(\mathrm{m})\end{array}$ & $\begin{array}{c}\text { Live } \\
\text { crown } \\
(\mathrm{m})\end{array}$ & $\begin{array}{c}\text { Live } \\
\text { crown } \\
(\%)\end{array}$ & $\begin{array}{c}\text { Age } \\
(\mathrm{y})\end{array}$ \\
\hline $\begin{array}{l}\text { Cut-to-length } \\
\text { Burned }\end{array}$ & $41.7 \mathrm{~b}$ & $21.3 \mathrm{a}$ & $12.7 \mathrm{a}$ & $60 \mathrm{ab}$ & $112 \mathrm{a}$ \\
$\begin{array}{l}\text { Unburned } \\
\text { Whole-tree }\end{array}$ & $42.5 \mathrm{ab}$ & $20.6 \mathrm{a}$ & $13.7 \mathrm{a}$ & $66 \mathrm{ab}$ & $103 \mathrm{a}$ \\
$\begin{array}{l}\text { Burned } \\
\text { Unburned }\end{array}$ & $43.4 \mathrm{ab}$ & $21.8 \mathrm{a}$ & $13.3 \mathrm{a}$ & $62 \mathrm{ab}$ & $102 \mathrm{a}$ \\
$\begin{array}{l}\text { Unthinned } \\
\text { Burned }\end{array}$ & $49.4 \mathrm{a}$ & $23.6 \mathrm{a}$ & $13.2 \mathrm{a}$ & $56 \mathrm{bc}$ & $104 \mathrm{a}$ \\
Unburned & $43.9 \mathrm{ab}$ & $20.7 \mathrm{a}$ & $10.2 \mathrm{~b}$ & $49 \mathrm{c}$ & $106 \mathrm{a}$ \\
\hline
\end{tabular}

* Within each variable, means sharing a common letter do not differ significantly at $\alpha=0.05$ according to Duncan's New Multiple Range Test $n=5$ for each thinning $\times$ prescribed fire treatment combination.

\section{RESULTS}

\subsection{Stand and site attributes}

In trees $\geqslant 25.4 \mathrm{~cm} \mathrm{DBH}$, mean DBH was $38.2 \mathrm{~cm}$ and mean height was $18.2 \mathrm{~m}$ for the stand overall prior to the implementation of the thinning treatments. DBH was larger ( $p=0.0217$ ) in the whole-tree subunit by $12 \%$ compared to that of the cut-to-length treatment and by $8 \%$ in comparison with the unthinned control, with the inequality arising primarily in the portion of the whole-tree treatment designated to remain unburned $(p=0.0425$ for the thinning $\times$ prescribed fire treatment interaction effect). Height, however, did not vary among any of the treatments according to ANOVA. Despite the noted minor disparities in mean DBH, total basal area did not differ significantly among any of the treatments prior to thinning and averaged $25.6 \mathrm{~m}^{2} \mathrm{ha}^{-1}$ for the stand overall. Following thinning, residual basal areas were $15.3 \mathrm{~m}^{2} \mathrm{ha}^{-1}$ and $15.1 \mathrm{~m}^{2} \mathrm{ha}^{-1}$ in the cut-to-length and whole-tree treatments, respectively, both of which were significantly lower ( $p=0.0293$ ) than the $21.7-\mathrm{m}^{2} \mathrm{ha}^{-1}$ basal area of the unthinned control. Residual basal areas in the two harvested subunits did not differ significantly according to DNMRT and, within all three thinning treatments, differences between portions to be burned and those to remain unburned were nonsignificant after thinning.

Mean DBH of the 30 site trees at the beginning of the 2003 growing season was $43.8 \mathrm{~cm}$ with an average height of $21.4 \mathrm{~m}$ (Tab. I), values that did not differ significantly among treatments according to ANOVA, although DNMRT revealed that site trees in the unburned portion of the whole-tree subunit were somewhat larger in DBH than those of this fire treatment in the unthinned control and those in the burned portion of the cut-to-length treatment. Mean live crown length and percentage were $12.9 \mathrm{~m}$ and $61 \%$, respectively, but in the case of both variables values tended to be higher in unburned than in burned stand portions ( $p=0.0114$ for crown length and $p=0.0291$ for percentage) with the exception of the whole-tree subunit where the reverse was true, while the contrast was sharpest between burned and unburned portions of the unthinned subunit $(p=0.0281$ and $p=0.0046$ for the thinning $\times$ prescribed fire treatment interaction effect on crown length and percentage, respectively). Mean site tree age was 105 years and did not vary among treatments. Coupled with height, the age of the site trees indicates that this stand occupies an $\mathrm{SI}_{100} 21$ site (index height in $\mathrm{m}$ ) for Jeffrey pine.

\subsection{Stem dimensional fluctuation}

A significant thinning influence ( $p=0.0016$ ) on maximum diurnal change in DBH (Fig. 1) was revealed by ANOVA. The thinning effect was most apparent in the September and October 2003 measurements when contraction of stems was greater overall in the cut-to-length and whole-tree subunits than in the unthinned control, although DNMRT indicated that significant disparities were restricted to the burned portion of the cut-to-length treatment and the unburned portion of the whole-tree treatment in the September measurements and were present only when the burned portion of the unthinned control was the basis of comparison in October. On the other nine measurement days, however, the thinning influence was less pronounced ( $p=0.0015$ for the thinning treatment $\times$ day of measurement interaction effect). Nevertheless, in the May 2003 measurements, DNMRT indicated that larger decreases in diameter were evident in the unburned portion of the whole-tree subunit than in that of the unthinned control, and in the January 2004 measurements, stems contracted more in the unburned portion of the cut-to-length treatment than in the burned, whole-tree treatment combination. Averaged across treatments, differences among measurement days in the extent of stem diameter fluctuation were also indicated $(p<0.0001)$, with the greatest contraction overall occurring late in the growing season while very little shrinkage, and even some swelling in the case of the February 2004 measurements, was observed during colder months.

Maximum relative fluctuation in DBH largely paralleled that of absolute change noted above, with a pronounced thinning effect ( $p=0.0071)$ again occurring primarily in the September and October 2003 measurements $(p=0.0101$ for the thinning treatment $x$ day of measurement interaction effect). In this case, however, only the cut-to-length treatment deviated from the control in September, and with DNMRT again indicating that the disparity did not extend to the unburned portion of the cut-to-length subunit, while in October, significant differences were again revealed only when the burned portion of the unthinned treatment was the basis of comparison, although as with absolute change, they extended to both the cut-to-length and whole-tree subunits regardless of fire treatment (Fig. 2). While not attributable to thinning as such, DNMRT indicated additional treatment differences in relative DBH fluctuation for January 2004, with greater contraction in the unburned portions of the cut-to-length and unthinned treatments than in the burned portion of the whole-tree subunit, which for the former extended to the unburned portion of the whole-tree treatment as well. Similar to those found in absolute DBH fluctuation, differences among measurement 


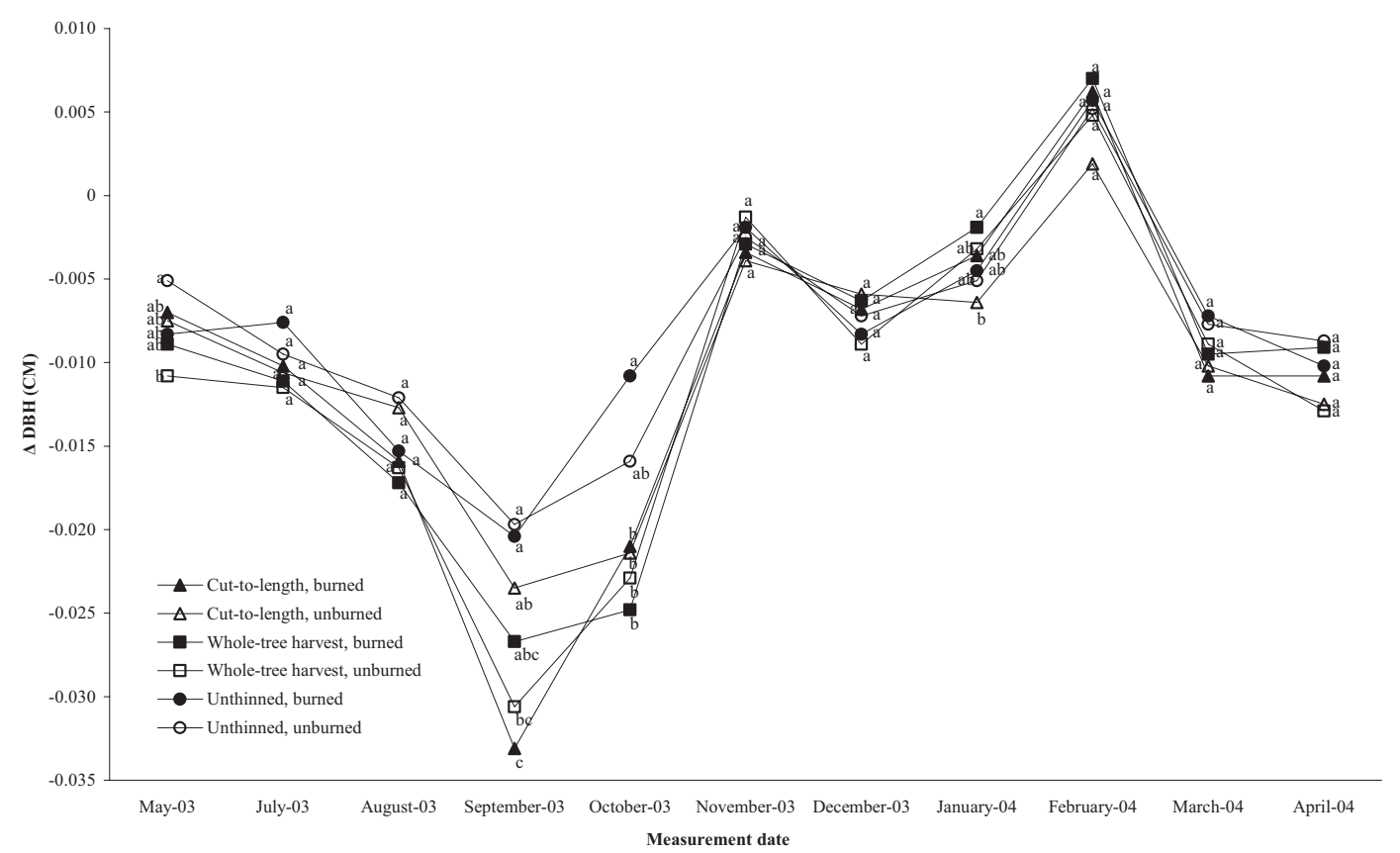

Figure 1. Maximum diurnal fluctuation $(\Delta)$ in DBH by measurement date as influenced by thinning and prescribed fire treatment. For each measurement date, means sharing a common letter do not differ significantly at $\alpha=0.05$ according to Duncan's New Multiple Range Test; $n=5$ for each thinning $\times$ prescribed fire treatment combination.

days in relative DBH change when averaged across treatments tended to be seasonal in nature $(p<0.0001)$, with the largest amount of contraction relative to tree diameter also generally encountered in the latter part of the growing season, while only minor decreases as well as a marginal diameter increase, again specifically in February 2004, prevailed in late fall and winter.

During the growing season months of approximately May through October, diurnal stem dimensional fluctuation in all treatments followed a highly regular pattern (Fig. 3). Typically, contraction began between 0700 and $1100 \mathrm{~h}$ with a peak rate of reduction occurring between 1200 and $1400 \mathrm{~h}$. Maximum shrinkage, without exception, was not observed until 1600 to $1900 \mathrm{~h}$ and recovery in bole dimensions was not evident until after sunset. Outside of the growing season, the diurnal pattern was similar to that during the growing season except that stem contraction in many cases would not begin until after $1100 \mathrm{~h}$ at the earliest and, as noted previously, the extent to which shrinkage occurred was much reduced. Additionally, in some trees, and in the case of the February 2004 measurements nearly all of them, swelling of the stems persisted throughout the day on several dates during colder months. Nevertheless, where reductions in stem dimensions did occur, minima were consistently reached immediately prior to sunset and swelling was delayed until after complete darkness had fallen.

\subsection{Relationships among variables}

In examining influences of site tree and stand attributes on maximum diurnal stem dimensional fluctuation, numerous significant models were revealed but few that explained substantial amounts of the variation in the dependent variables
(Tab. II). Among significant models assessing the influence of site tree characteristics, DBH was found to be negatively correlated with diurnal changes in this dimension in the August 2003 measurements. However, this relationship was weak, as variation in site tree diameter explained only about one-fifth of that in DBH fluctuation. Models evaluating effects of site tree live crown length and percentage on changes in stem dimensions also yielded several significant correlations, but these again were of limited predictive value. Nevertheless, DBH fluctuation in July and October 2003 was negatively correlated with live crown length, while relative change in DBH was negatively correlated with this variable in October 2003 as well, but also with crown percentage in July 2003. In each case, variation in the live crown attributes explained one-quarter or less of that in the dependent variables. As for influences of stand attributes, residual basal area was positively correlated with diurnal changes in DBH in the December 2003 and April 2004 measurements and with relative changes in this variable in the May, September, and December 2003 as well as the April 2004 measurements, but all of these relationships were exceedingly weak also, as this independent variable explained less than one-quarter of the variation in the respective dependent variables.

\section{DISCUSSION}

Results of this investigation suggest that thinnings removing approximately one-half of initial basal area had a positive effect on stem water recharge capacity in Jeffrey pine, particularly during the late portion of the growing season when water availability is typically most limited in this dry forest 


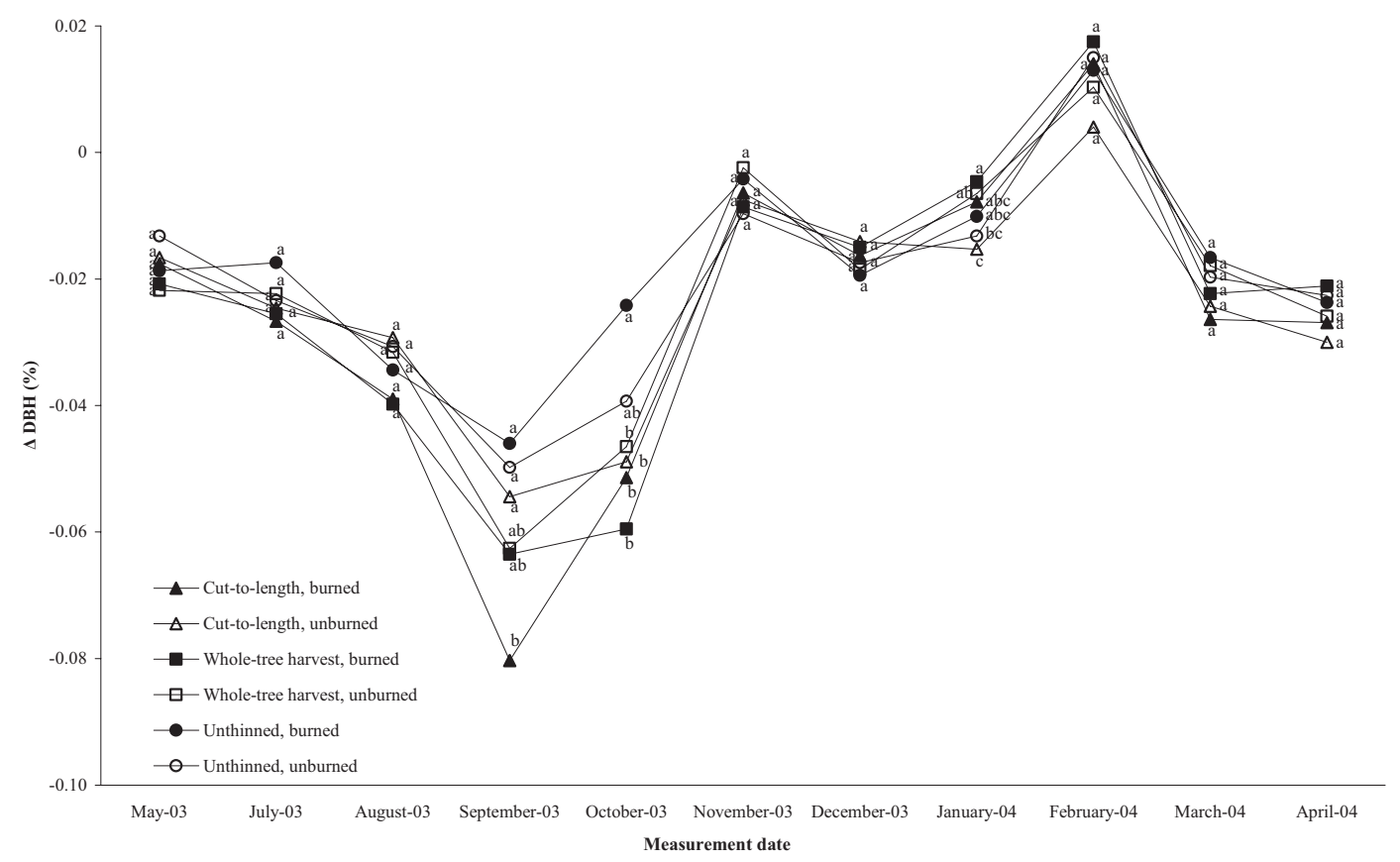

Figure 2. Maximum diurnal fluctuation $(\Delta)$ in DBH relative to initial DBH by measurement date as influenced by thinning and prescribed fire treatment. For each measurement date, means sharing a common letter do not differ significantly at $\alpha=0.05$ according to Duncan's New Multiple Range Test; $n=5$ for each thinning $\times$ prescribed fire treatment combination.

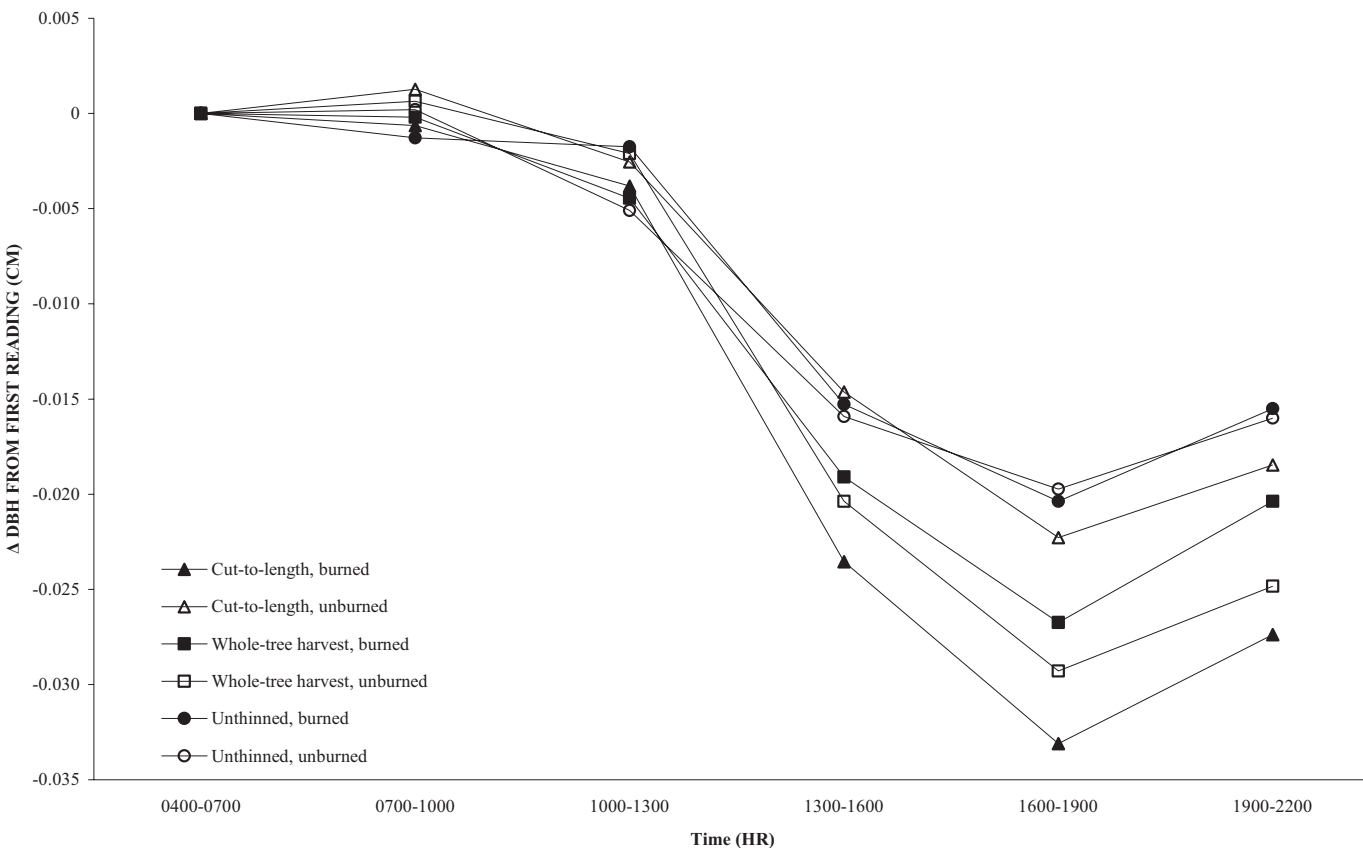

Figure 3. Typical diurnal pattern of stem DBH flux $(\Delta)$ in Jeffrey pine site trees during growing season by thinning and prescribed fire treatment. Shown are data from the September 2003 measurement date. 
Table II. Significant simple linear regressions based on all treatments included in the study and relating maximum stem dimensional flux $(\Delta)$ to site tree and stand variables*.

\begin{tabular}{|c|c|c|c|c|}
\hline $\begin{array}{l}\text { Dependent } \\
\text { Variable }\end{array}$ & $\begin{array}{l}\text { Independent } \\
\text { variable }\end{array}$ & Correlation & $\begin{array}{c}\mathrm{F} \text { test } \\
p \text {-value } \\
\text { for model }\end{array}$ & $\begin{array}{c}\text { Model } \\
r^{2}\end{array}$ \\
\hline \multicolumn{5}{|l|}{$\overline{\Delta \mathrm{DBH}}$} \\
\hline August 2003 & $\mathrm{DBH}$ & Negative & 0.0119 & 0.2053 \\
\hline July 2003 & Live crown length & & 0.0215 & 0.1748 \\
\hline October 2003 & Live crown length & & 0.0045 & 0.2539 \\
\hline December 2003 & Residual basal area & Positive & 0.0463 & 0.1344 \\
\hline $\begin{array}{l}\text { April } 2004 \\
\% \Delta \mathrm{DBH}\end{array}$ & Residual basal area & Positive & 0.0178 & 0.1845 \\
\hline Octo & & & 0.0228 & 0.1717 \\
\hline July 2003 & Live crown percentage & Negative & 0.0295 & 0.1582 \\
\hline May 2003 & Residual basal area & Positive & 0.0436 & 0.1376 \\
\hline September 2003 & Residual basal area & & 0.0380 & 0.1448 \\
\hline December 2003 & Residual basal area & Positive & 0.0425 & 0.1389 \\
\hline April 2004 & Residual basal area & Positive & 0.0082 & 0.2240 \\
\hline
\end{tabular}

* For each regression, results are based on 30 observations.

type. This response was manifested in two measures of maximum diurnal stem dimensional fluctuation, specifically absolute and relative changes in individual tree DBH. For each of these variables, September and October 2003 measurements revealed that the cut-to-length and whole-tree treatments resulted in greater stem contraction than that in the unthinned control, although mean separation analysis indicated that significant disparities did not extend to both the cut-to-length and whole-tree treatments in all such comparisons, and in some cases existed only when one or the other of the fire treatments was considered. Nevertheless, averaged across fire treatments, stem shrinkage in the thinned stand portions was $55 \%$ greater on the basis of DBH than in the unthinned control on these two measurement days, while DBH contraction relative to initial tree diameter was $49 \%$ greater. In contrast, evidence of a thinning influence on bole contraction earlier in the growing season was relatively muted or absent entirely. Overall, these results suggest that more soil water was available for recharge of stem storage tissues, and thus continued depletion via transpiration, in the thinned subunits of the stand during the latter part of the growing season, whereas earlier in the season soil moisture was apparently sufficient throughout the stand to adequately replenish this reservoir and satisfy transpirational demand, thus producing relatively little distinction among treatments. Alternatively, treatment differences may have been somewhat concealed early in the season by relatively rapid daily radial growth in the thinned subunits, and radial growth has been documented to have been enhanced by thinning in this stand [12], thus counteracting the measurable effects of stem contraction due to increased transpiration. The latter assertion seems especially plausible given the lower xylem water potentials in the unthinned compared to the thinned stand portions throughout the corresponding growing season reported by Walker et al. [41] for this site. Regardless, the assertion here that greater bole contraction is indicative of reduced moisture stress is supported by the findings of Zaerr [46], which demonstrated that during a period of minimal natural rainfall, irrigated Douglas-fir (Pseudotsuga menziesii [Mirb.] Franco) trees exhibited more shrinkage than controls. Furthermore, results reported here concerning late season tree water status also generally concur with those from water relations studies using different measurement approaches conducted in wetter forests of younger age including Douglas-fir [2, 5], lodgepole pine (Pinus contorta Dougl. ex. Loud.) [10,29], balsam fir (Abies balsamea [L.] Mill.) and white birch (Betula papyrifera Marsh.) [28], each of which established that moisture was rendered more available to trees subsequent to thinning. However, others have reported elevated moisture stress in response to this management practice in some instances, specifically in young plantations of loblolly pine (Pinus taeda L.) $[7,14,36]$ as well as in old-growth ponderosa pine [34], which was attributed to increased crown exposure and therefore higher stomatal conductance.

Lacking here was clear evidence that the harvesting approach used in thinning the stand was of consequence to diurnal fluctuation in stem dimensions during the growing season despite the substantial differences between the two systems in forest floor impacts [42]. Evidence that prescribed fire affected water storage capabilities in this stand was also not forthcoming. The absence of negative underburning effects suggests that damage to root systems or vascular tissues in the lower bole, injuries sometimes occurring with this management practice in several species $[30,31,35]$, did not occur here.

Diurnal patterns of stem dimensional fluctuation observed during the growing season were similar to those reported in other investigations. As in the present study, contraction typically began within a few hours of sunrise and continued until late in the afternoon or through the early evening hours in Douglas-fir [23, 46], red pine (Pinus resinosa Ait.) [37], and mature Norway spruce (Picea abies [L.] Karst.) [47]. However, in a separate study of red pine [21] as well as in young, potted Norway spruce [48] in which shrinkage also commenced shortly after sunrise, maximum contraction occurred in midafternoon and even early afternoon, respectively, after which swelling was observed through the evening and night. The magnitude of shrinkage during the growing season here was also comparable to that observed in some studies [46, 47] but larger than that reported by either Lassoie [23] or Turner and Waggoner [37] under similar atmospheric conditions.

The extent to which stems contracted on a given day generally increased as the growing season unfolded regardless of treatment, suggesting an increasing reliance upon stored water in the bole for daily transpirational requirements as soils became progressively drier. A minor reversal in this trend in all treatments was evident in October 2003, possibly indicating that soil water was becoming increasingly inaccessible to trees in the last weeks of the growing season, prompting the closure of stomata earlier in the day and resulting in less total transpiration. This pattern is similar to that reported by Kozlowski and Winget [21] in northern pin oak (Quercus ellipsoidalis Hill), quaking aspen (Populus tremuloides Michx.), and red pine except that in these three species bole contraction had already decreased substantially by late summer. Nevertheless, 
in the present investigation, only a minor amount of daytime stem contraction was generally observed during the late fall and winter months when photosynthetic rates and thus transpiration were probably quite low. This is also a period in which it has been previously noted that significant rehydration of sapwood occurs [44]. Furthermore, in a complete departure from the responses observed during any other part of the year, the February 2004 measurements revealed a small degree of bole swelling throughout the day in all treatments. This may have occurred as a result of particularly cold air temperatures prevalent on this day, resulting in substantially reduced photosynthesis and therefore diminished water loss that enabled stem water to be slowly replenished even during daylight hours, as Waring and Running [43] have observed that cold weather constrains sap flow because of its higher viscosity at low temperatures. It is also possible that freezing of sap may, in part, account for the observed bole swelling on this day, although Jeffrey pine is noted for its ability to tolerate extremely low temperatures [32]. Regardless, by March and April 2004, diurnal patterns of stem dimensional fluctuation began to resemble those of the early growing season observed the previous year.

Regression analyses revealed a marginal negative correlation between diurnal changes in stem $\mathrm{DBH}$ and initial site tree diameter during a single growing season month. This finding suggests that to some extent, larger diameter trees exhibited greater amounts of contraction, possibly a product of more sapwood area and thus greater internal storage capacity. Variation among individual site trees in live crown length and percentage was of minor consequence to diurnal fluctuation in stem dimensions, as negative correlations between the former variables and the latter were weak and infrequent, but to the extent present indicated that greater contraction occurred in trees with larger crowns. This suggests that stored stem water was used in higher amounts in response to elevated transpirational demand resulting from increased foliar surface area $[19,20]$.

Also significant, but again weak overall, were regressions relating diurnal changes in $\mathrm{DBH}$, both in absolute and relative terms, to residual stand basal area, the only variable examined here that was directly altered by thinning. Correlations involving these variables were positive and thus indicated limited stem contraction with increasing basal area, thus providing some measure of evidence that the differences between thinned and unthinned subunits in the magnitude of reduction in stem dimensions discussed previously likely resulted from an increased availability of soil water for stem recharge in the former. However, the measurement dates on which some of these models were based did not coincide with those on which significant differences between thinned and unthinned plots were revealed, rendering their utility questionable, especially when coupled with the tenuous nature of the correlations involved.

In summary, these results indicate that thinning using cutto-length and whole-tree harvesting systems increased late growing season water availability to dominant and codominant Jeffrey pine in a stand over a century old. This response was manifested in daily absolute and relative contraction in DBH that were greater in thinned stand portions than in an un- thinned control. Substantive disparities between the two harvesting approaches were largely absent, and prescribed fire had no discernible impact on stem water recharge capacity as measured by the above variables. Seasonal variation in stem dimensional flux was apparent, as diurnal changes in bole size were greatest in the late growing season, while fluctuation was less pronounced in the early season and was at a minimum in the late fall and winter months when rehydration of depleted storage tissues was presumably taking place. Factors identified as influencing stem dimensional fluctuation to some extent included site tree DBH and live crown attributes as well as residual stand basal area. Overall, this study demonstrated significant benefits of density management for water relations in an older, dry site forest type and no apparent compromise of these benefits with subsequent broadcast underburning.

Acknowledgements: Support for this research was provided by the Nevada Agricultural Experiment Station Projects 523M, 523P, and 5262 funded by the McIntire-Stennis Cooperative Forestry Research Program. Publication No. 52077051 of the Nevada Agricultural Experiment Station. The authors are indebted to D. Brunson, J. Chacon, G. Fernandez, T. Gunder, J. Holcomb, K. Jones, C. McCarthy, B. Melville, K. Murphy, J. Roubique, R. Salas, G. Schall, R. Shane, J. Spurlock, and T. Wallace for their assistance.

\section{REFERENCES}

[1] Arno S.F., Fire in western forest ecosystems, in: Brown J.K., Smith J.K. (Eds.), Wildland fire in ecosystems: effects of fire on flora, USDA For. Serv. Gen. Tech. Rep. RMRS-GTR-42, Vol. 2, Ogden, UT, 2000, pp. 97-120.

[2] Aussenac G., Granier A., Effects of thinning on water stress and growth in Douglas-fir, Can. J. For. Res. 18 (1988) 100-105.

[3] Barrett J.W., McDonald P.M., Ronco F. Jr., Ryker R.A., Interior ponderosa pine, in: Eyre, F.H. (Ed.), Forest cover types of the United States and Canada, Soc. Am. For., Washington, DC, 1980, pp. 114-115.

[4] Brennan L.A., Hermann S.M., Prescribed fire and forest pests: solutions for today and tomorrow, J. For. 92 (1994) 34-37.

[5] Brix H., Mitchell A.K., Thinning and nitrogen fertilization effects on soil and tree water stress in a Douglas-fir stand, Can. J. For. Res. 16 (1986) 1334-1338.

[6] Christiansen E., Waring R.H., Berryman A.A., Resistance of conifers to bark beetle attack: searching for general relationships, For. Ecol. Manage. 22 (1987) 89-106.

[7] Cregg B.M., Hennessey T.C., Dougherty P.M., Water relations of loblolly pine trees in southeastern Oklahoma following precommercial thinning, Can. J. For. Res. 20 (1990) 1508-1513.

[8] Curtis R.O., Marshall D.D., Why quadratic mean diameter? West. J. Appl. For. 15 (2000) 137-139.

[9] Davis L.C., Johnson K.N., Bettinger P.S., Howard T.E., Forest management, 4th ed., McGraw-Hill, New York, 2001, 804 p.

[10] Donner B.L., Running S.W., Water stress response after thinning Pinus contorta stands in Montana, For. Sci. 32 (1986) 614-625.

[11] Edmonds R.L., Agee J.K., Gara R.I., Forest health and protection, McGraw-Hill, New York, 2000, 630 p.

[12] Fecko R.M., Walker R.F., Frederick W.B., Johnson D.W., Miller W.W., Influences of mechanized thinning and prescribed underburning on radial growth of Jeffrey pine, J. Sustain. For. (2008) in press. 
[13] Fisher R.F., Binkley D., Ecology and management of forest soils, 3rd ed., John Wiley and Sons, New York, 2000, 489 p.

[14] Ginn S.E., Seiler J.R., Cazell B.H., Kreh R.E., Physiological and growth responses of eight-year old loblolly pine stands to thinning, For. Sci. 37 (1991) 1030-1040.

[15] Hallin W.E., The application of unit area control in the management of ponderosa-Jeffrey pine at Blacks Mountain Experimental Forest, USDA For. Serv. Tech. Bull. 1191, Washington, DC, 1959, 96 p.

[16] Helms J.A., The California region, in: Barrett J.W. (Ed.), Regional silviculture of the United States, 3rd ed., John Wiley and Sons, New York, 1995, pp. 441-497.

[17] Jenkinson J.L., Pinus jeffreyi Grev. \& Balf. Jeffrey pine, in: Burns R.M., Honkala B.H. (Tech. Coords.), Silvics of North America: Vol. 1, Conifers, USDA For. Serv. Agric. Handb. 654, Washington, DC, 1990 , pp. 359-369.

[18] Kozlowski T.T., Diurnal variations in stem diameters of small trees, Bot. Gazette 128 (1967) 60-68.

[19] Kozlowski T.T., Kramer P.J., Pallardy S.G., The physiological ecology of woody plants, Academic Press, New York, 1991, 657 p.

[20] Kozlowski T.T., Pallardy S.G., Physiology of woody plants, 2nd ed., Academic Press, New York, 1997, 411 p.

[21] Kozlowski T.T., Winget C.H., Diurnal and seasonal variation in radii of tree stems, Ecology 45 (1964) 149-155.

[22] Kramer P.J., Water relations of plants, Academic Press, New York, 1983, 489 p.

[23] Lassoie J.P., Diurnal dimensional fluctuations in a Douglas-fir stem in response to tree water status, For. Sci. 19 (1973) 251-255.

[24] Laudenslayer W.F. Jr., Darr H.H., Smith S., Historical effects of forest management practices on eastside pine communities in northeastern California, in: Tecle, A., Covington, W.W. (Tech. Coords.), Multiresource management of ponderosa pine forests, USDA For. Serv. Gen. Tech. Rep. RM-185, Fort Collins, CO, 1989, pp. 26-34.

[25] MacDougal D.T., Tree growth, Chronica Botanica Co., Waltham, MA, 1938, 240 p.

[26] Meyer W.H., Yield of even-aged stands of ponderosa pine, USDA Tech. Bull. 630, Washington, DC, 1938, 59 p.

[27] Nyland R.D., Silviculture: concepts and applications, 2nd ed., McGraw-Hill, New York, 2002, 682 p.

[28] Pothier D., Margolis H.A., Changes in the water relations of balsam fir and white birch saplings after thinning, Tree Physiol. 6 (1990) 371-380.

[29] Reid D.E.B., Silins U., Lieffers V.J., Sapwood hydraulic recovery following thinning in lodgepole pine, Ann. For. Sci. 63 (2006) 329338 .

[30] Ryan K.C., Frandsen W.H., Basal injury from smoldering fires in mature Pinus ponderosa Laws., Int. J. Wildl. Fire 1 (1991) 107 118 .

[31] Ryan K.C., Reinhardt E.D., Predicting postfire mortality of seven western conifers, Can. J. For. Res. 18 (1988) 1291-1297.

[32] Sakai A., Weiser C.J., Freezing resistance of trees in North America with reference to tree regions, Ecology 54 (1973) 118-126.
[33] Saveland J.M., Neuenschwander L.F., Changing stand density and composition with prescribed fire, in: Schmidt W.C. (Comp.), Proceedings - future forests of the Mountain West: a stand culture symposium, USDA For. Serv. Gen. Tech. Rep. INT-243, Ogden, UT, 1988, pp. 330-331.

[34] Stone J.E., Kolb T.E., Covington W.W., Effects of restoration thinning on presettlement Pinus ponderosa in northern Arizona, Restor. Ecol. 7 (1999) 172-182.

[35] Swezy D.M., Agee J.K., Prescribed fire effects on fine-root and tree mortality in old-growth ponderosa pine, Can. J. For. Res. 21 (1991) 626-634.

[36] Tang Z., Chambers J.L., Guddanti S., Barnett J.P., Thinning, fertilization, and crown position interact to control physiological responses of loblolly pine, Tree Physiol. 19 (1999) 87-94.

[37] Turner N.C., Waggoner P.E., Effects of changing stomatal width in a red pine forest on soil water content, leaf water potential, bole diameter, and growth, Plant Physiol. 43 (1968) 973-978.

[38] Urretavizcaya M.F., Defossé G.E., Gonda H.E., Short-term effects of fire on plant cover and soil conditions in two Austrocedrus chilensis (cypress) forests in Patagonia, Argentina, Ann. For. Sci. 63 (2006) 63-71.

[39] USDA Forest Service, Soil survey of the Tahoe National Forest area, California, USDA For. Serv. Pacific Southwest Region, San Francisco, CA, 1994, 377 p.

[40] Van Mantgem P., Schwartz M., An experimental demonstration of stem damage as a predictor of fire-caused mortality for ponderosa pine, Can. J. For. Res. 34 (2004) 1343-1347.

[41] Walker R.F., Fecko R.M., Frederick W.B., Johnson D.W., Miller W.W., Todd D.E., Murphy J.D., Influences of thinning and prescribed fire on water relations of Jeffrey pine: xylem and soil water potentials, J. Sustain. For. 23 (4) (2006) 35-59.

[42] Walker R.F., Fecko R.M., Frederick W.B., Murphy J.D., Johnson D.W., Miller W.W., Thinning and prescribed fire effects on forest floor fuels in the east side Sierra Nevada pine type, J. Sustain. For. 23 (2) (2006) 99-115.

[43] Waring R.H., Running S.W., Sapwood water storage: its contribution to transpiration and effect upon water conductance through the stems of old-growth Douglas-fir, Plant Cell Environ. 1 (1978) 131140 .

[44] Waring R.H., Schlesinger W.H., Forest ecosystems: concepts and management, Academic Press, New York, 1985, 340 p.

[45] Weaver H., Fire - Nature's thinning agent in ponderosa pine stands, J. For. 45 (1947) 437-444.

[46] Zaerr J.B., Moisture stress and stem diameter in young Douglas-fir, For. Sci. 17 (1971) 466-469.

[47] Zweifel R., Häsler R., Dynamics of water storage in mature subalpine Picea abies: temporal and spatial patterns of change in stem radius, Tree Physiol. 21 (2001) 561-569.

[48] Zweifel R., Item H., Häsler R., Link between diurnal stem radius changes and tree water relations, Tree Physiol. 21 (2001) 869-877. 